\title{
A Strategic Approach to Reputation Management and its Reflections on \\ Sustainable Competitiveness.
}

\author{
Pınar Altıok Gürel, Phd \\ ${ }^{a}$ Faculty of Economics and Administrative Sciences, Beykent University. Turkey
}

\begin{abstract}
Due to the issues brought about by the current Information Age, such as rapid development of technology, easy and fast access to information, increases in international relations and global market perception, companies were compelled to seek for sustainable competitive advantage, and in this sense, the concept of "corporate reputation", which is powered by unique and original values of a corporation and which cannot be "imitated", has started to draw attention. In our day when markets are gradually reaching the point of saturation and consumers are getting the chance to evaluate more and more options, the efforts to create a convincing difference in minds have become prominent, and subsequently, reputation management has become an important field which a company needs to effectively manage. Corporate reputation management and the communication types the company will adopt in this sense have gained importance in all areas related to strategic management elements, from market positioning of products to shaping of intellectual perception maps. Corporate reputation management, wherein integrated marketing communication and public relation activities extremely important roles, needs to be strategically managed. Management of the concept of corporate reputation, which is a product of tangible and intangible corporate components, have transformed into a strategic requirement and become an field of its own as "corporate reputation management" within modern business administration. The fact that corporate reputation management, which has a relation with almost all activity fields of a company, is in contact with elements such as corporate social responsibility, management based on ethical principles, performance assessment studies in human resources management and the of phenomenon of governance, the recent agenda, which all affect the field of sustainable competition, indicates that this concept should be evaluated in terms of business management strategy.
\end{abstract}

Keywords: Strategy, Management, Reputation, Competitiveness

JEL Code: D23, M 54

\section{(C) 2014 Published by SSBFNET}

\section{Introduction}

Corporate reputation management is a multidimensional concept which requires studies based on interdisciplinary approaches. Moving forward from the understanding that abstract values, beside physical resources, will create a unique/original/authentic identity towards the goal of providing differentiation, the requirement of a company to manage a corporate reputation, which is to be supported by the society, affects the preferences the consumers make among many options, in the new business administration sense wherein customer-oriented strategies have become prominent. A company will be able to realize its goal of continuous development and expansion, beside the goal of

\footnotetext{
${ }^{\mathrm{a}}$ Corresponding author.
} 
profits, upon the support it receives from customers, investors, suppliers and society which are the basic groups providing resources to it. For this reason, serious long-term investments are required for a corporate reputation. Especially due to its many positive effects such as the ability to survive periods of crisis due to the perception of corporate reputation it provides, being in a competitively advantageous position and gaining time in implementation of certain decisions, corporate reputation management is a strategic management field which requires serious handling by companies.

Variables of a company such as management quality, HR applications, relations with shareholders, social responsibility projects formed in line with expectations of the society and the type of approach against internal customers affect shareholder perception and form a new perception in the shape of differences separating the institution from its rivals. For this reason, this conception, which has significant importance in terms of sustainable competition, must be managed with a disciplined understanding. This study discusses the matters that have recently arisen due to the multidisciplinary structure of the subject.

The first section generally touches upon the concepts of reputation and corporate reputation and emphasizes the current necessity of managing corporate reputation. The second section discusses basic elements that constitute corporate reputation and the Harris-Fomburn Reputation Quotient (RQ) Model, which has a wide area of application in reputation measurement. In the third section a necessity of emphasizing intersection points between the components within the concept of governance having recent currency in terms of public sector, private sector and Non-Profit Organizations, and corporate reputation management, has arisen. Since communication plays a vital role in corporate reputation management, the fourth section addresses the subject of corporate reputation communication and then examines the key roles assumed by integrated marketing communication and public relations in this process.

Pursuing ethical principles in corporate social responsibility studies and its relation with corporate reputation management are the subjects of the fifth section. Sixth section of the study touches upon performance indicators and the fact that non-financial values should be reflected as much as financial values, as a requirement of the context established together with the dimension of human resources which constitutes an important shareholder society of corporate reputation management, and from this point forward, a connection is established between utilization of multidimensional performance assessments and corporate reputation management. At the final chapter, conclusions of the study are presented and various determinations are made on the subject together with a general evaluation.

\section{The Concepts of Reputation and Corporate Reputation}

Socrates' quote embodied as "... credit is like fire, when once you have kindled it you may easily preserve it, but if you once extinguish it, you will find it an arduous task to rekindle it again (Uztuğ, Şener et al., 2012:117) call out to our day from ages before, with the same importance.

Reputation is defined as general thoughts of people about a person or a concept and the level of appreciation and admiration upon a subject or a person based on past behaviors or character (Uztuğ, Şener et al., 2012:134). Corporate reputation is a multifaceted component which focuses on what is being done and adopted methods in corporations and 
which is based on perception in connection with shareholder experiences (Şatır \& Sümer;2006:51) and the perception of in-house and off-house target audiences about the corporation (Uztuğ, Şener et al., 2012:119) and it is defined by perceptions of different shareholders and basic images (Uztuğ, Şener et al., 2012:119). In this sense, corporate reputation is one of the most important strategic resources and decisions of shareholders defined the corporation's competitive position (Gümüş \& Öksüz, 2009: 2131). Because, the reputation of the corporation involves feelings, ideas and impressions of social shareholders and consists more of perceptions (Uztuğ, Şener et al., 2012:117). Corporate reputation, while respecting every value of the society, also involves all types of laws, directives, rules and applications which will enable it to create value for its customers in the long term (Argüden, 2013:10). Therefore, corporate reputation can be qualified as a product of a company's network of shareholders, and the perception of this network against the company throughout the history (Sarıkaya \& Oruç, 2010:96). Due to accelerating effects of the globalization, reputation has become more important for corporations as well as people and changed into a strategic power which needs careful management by companies.

The concept of reputation, which is associated with quantities such as respectability and reliability, creates a perception related to respect shown by the society to individuals and corporations. In this sense, corporate reputation is the contribution of a trust, created by an organization, to market value (Kadıbeşgil, 2006;55). For this reason and due market conditions brought about by globalization, reputation has become a very important concept of care for public sector, private sector and non-profit non-governmental organizations in order to realize their goals and develop themselves in the competitive environment (Watson \& Kitchen, 2010:512).

The concept of "reputation" which expresses the belief that a person or a corporation possesses a specific attribute, carrying a generally acknowledged / valued structure and a characteristic and respectable position, is seen as an important matter of resource making in a world where corporate works have come fore (Watson \& Kitchen, 2010:512).

Corporate reputation can be explained as the process of controlling and directing thoughts, information and emotional responses of internal and external shareholders, namely the groups of corporate staff, customers, investors, stock holders and suppliers (Uztuğ, Şener et al., 2012:117).

Corporate reputation is a view summarizing perceptions of related shareholders of the corporation, in other words, it is the whole of evaluations on sensual and cognitive evaluations related to past performance of the corporation and forecasts on its future behaviors (Gümüş \& Öksüz, 2009:2131).

Beside, it is possible to express that corporate reputation is a type of collective representation which includes all visual and auditory perceptions that a company will construct through time, its corporate identity, its performance and its behaviors and reflects the multiple perspectives of a company (Watson \& Kitchen, 2010:512). In a sense, corporate reputation being a collective concept which involves ideas of all shareholders on the corporation's reputation, corporate internal identity and also the ideas of external shareholders and especially customers on the corporation's reputation, it is generally a long-term mixture of shareholder evaluations on corporate performance in fields such as 
"what the corporation is", "how the corporation fulfills its responsibilities", "how shareholder expectations are fulfilled" and "adjusting to social and politic environment" (Uztuğ, Şener et al., 2012:134).

Corporate reputation is the most valuable asset of companies. Corporate reputation management rises on three foundations, namely economic performance, social accountability and the ability to present valuable output for social shareholders (Uztuğ, Şener et al., 2012:134). This indicates to us, that corporate reputation is a concept which results from collectively managing tangible and abstract values. Corporate reputation is a value to be correctly managed as an agenct of strategic management. Reputation at corporate level is a phenomenon which enables companies to differentiate themselves among rivals, reflects unique and intellectual accumulation to the outer world and provides sustainable competition power in all its aspects. It is a result necessitated by globalization, that corporate reputation management components recently exhibit diversity within managerial business strategies.

Corporate reputation, includes relations with all shareholders. Because for a corporation, reputation means formation by the corporation the business consciousness in a field where prestige is emphasized within the context of identifying with social values, while carrying on its activities. The interaction a company will form with the society in general and with its shareholders in private will shape itself proportionally with the values it protected and brought in the past. Considering the fact that perception plays a privileged role in reputation, realized actions of a company such as timely and full realization of projects contracted by the company, company consistency in its actions and an image of a management which does preserve ethical principles will gradually positively reinforce the collective consciousness towards the company. For this reason, corporate reputation, which is a time-buying factor while planning strategies to be implemented against future threats from rivals, necessitates a rational management sense wherein perception together with realized matters are collated together, due to its multidimensional structure.

Corporate reputation forms as a result of all works of a corporation (Gümüş \& Öksüz, 2009:2130). Due to its sensitive and fragile structure, corporate reputation, which will provide competitive advantage in all the fields the company is contact with, the fields of retaining present customers, gaining new customers, new product launches, working with healthy distribution channels, marketing policies, pricing, advertisement campaigns being primary, obligates that business administration be extremely careful against risks they are to predict. Corporate reputation management must be strategically constructed so as to include different dimensions. At this point, "proactive", "defensive" and "reactive" perspectives must be approached as a whole. In that (Uztuğ, Şener et al., 2012:122); The proactive situation of corporate reputation management involves construction and preserving of the corporation's reputation, such reputation being defensive and protected against dangers in the awareness of the corporation against possible risks, and the reactive situation involves definition and implementation of restorative communication strategies aimed towards surviving periods of crisis with the least damage.

In our Post-Modern age, due to globalization, concepts within corporations' intangible resources such as information and information management ability, political business relationships, patents, computer software, nanotechnological/medical formulas, corporate culture, lifelong customer value and customer satisfaction level. Therefore, all innovative values of a company such as social status, brand image, its product range, the difference it has created as 
an organizational/experiental marketing method and different applications it has implemented in its management styles and beside, many tangible and abstract factors such as the monetary value of its brand, affect perception of the company by the society. Enabling easier and faster access to new markets is an important advantage in today's global market sense.

The subject of corporate reputation is increasingly discussed strategically and is gaining an important place in competitive advantage of companies (Sarıkaya \& Oruç, 2010:97). Beside corporate reputation being one of the basic elements differentiating companies from their rivals, it has been observed that a strong reputation provides important opportunities both economically and socially, therefore it has been needed that companies develop policies which involve all their shareholders and the environment within current conditions of (Sarıkaya \& Oruç, 2010:96) competition. Therefore, at this point it is useful to shortly touch upon "the advantages a strong corporate reputation will bring a company". Namely; a strong corporate reputation provides companies certain advantages (Uztuğ, Şener ve diğerleri, 2012:122) such as; bringing extra value to products and services of the corporation, assisting in lowering the risk perceived by consumers while purchasing products or services, positively affecting future stock values, playing roles in consumer preferences, enabling access to new global markets, getting more media coverage on corporate news, the ability to employ employees with more superior skills, gaining sustainable competitive advantage, concretizing the corporation's position within the industrial social system, decreasing the perceived risk and increasing tendency of shareholders into trusting the corporation.

Increasing personnel commitment to corporation, corporate reputation therefore assumes the role of a barrier protecting the corporation in periods of crisis and assists the business in surviving difficult periods suffering the least possible damage. Beside, a strong reputation paves the way for acceptance of the company by shareholders and for organizational integration, together with assuming the role of a staff incentive for organizations that are to work in a chaotic environment -maybe created by itself- (Watson \& Kitchen, 2010:512). Corporate reputation is one of the factors in making the preference of a company over another, therefore it gains competitive advantage to the company in new investments, international markets and joint ventures (Saylı \& Uğurlu, 2007:89). Corporate image is how shareholders see the organization (Karatepe, 2008:83). While a strong corporate image is important in terms of increasing foreign assets and equity capital, it is also thought that it has a positive effect on the ability to increase sales and prices (Karatepe, 2008:83). Corporate reputation brings qualified human resources to a company. Corporate reputation, while being an abstract concept, is reflected on production of tangible values in the long term due to its unique characteristic identity which cannot be imitated. A strong corporate reputation aids international expansion of a company (Watson \& Kitchen, 2010:512). Beside its financial values added to a company, corporate reputation also has contributions such as providing ease of entrance to new markets and minimizing risks of customers due to purchases.

Obviously corporate reputation is the reflection of a company's difference among its rivals. This difference is identical with a company's qualitative and quantitative caliber. Company personnel in all its departments and ranks are responsible for preserving this difference. It is clear that a strong reputation cannot be formed by accident (Watson $\&$ Kitchen, 2010:512). This certainly will develop primarily in connection with an effective leadership/management, then 
product and service quality, and most importantly, through communication activities kept up with shareholders and feedback mechanisms (Watson \& Kitchen, 2010:512). It is the company leader/manager who will convey to the staff that corporate reputation is an important strategic field of business management.

The leader/manager will create a vision which is in line with corporate identity, will pattern future objectives of the staff and the company and be adopted and implemented by all shareholders, and will structure the whole process within framework of corporate reputation management. This understanding, which consequently brings transparency in actions and relationships as a requirement of ethical management, necessitates responsibility for all employees in terms of corporate reputation understanding. Likewise, global competition has changed the development of communication technology, increase of social awareness and responsibilities of corporations and institutions against the society and necessitated accountability for them (Uztuğ, Şener et al., 2012:134). Having such a vital importance in operation of corporations, corporate reputation becomes stronger with ideas and applications such as environmental consciousness, quality awareness, transparency, customer satisfaction and business policies which are principled and consistent (Karatepe, 2008:83).

Corporate reputation both affects assets and opportunities of a company and improves under their influence. For this reason, having a positive corporate reputation may be regarded as a strategic resource for the organization (Saylı $\&$ Uğurlu, 2007:89). Considering all these factors, it must be regarded as a strategic necessity for companies, which tend to create difference, to manage corporate reputation components within a perception that will result in a winning situation for all social shareholders and base these components on principles of business ethics.

\section{Harris-Fombrun Reputation Quotient (RQ) Model within the Context of Basic Corporate Reputation} Components and their Measurement

While many criteria have been developed and are currently being developed for reputation measurement, all criteria are being shaped according to demands and needs of corporations' social shareholders (Uztuğ, Şener et al., 2012:134). Efforts were spent to measure corporate reputation components in many studies, for example; America's Most Admired Companis (AMAC), Global Most Admired Companies (GMAC), German Manager Magazin, Wirthlin Report, Benneth and Kottasz researches formed by Benneth and Kottasz and published in the Corporate Communication Magazine, researches conducted by the Society for Human Resource Management: SHRM (Şatır \& Sümer;200653-54). All of these researches provide meaningful perspectives. However, Harris-Fombrun Reputation Quotient (RQ) Model, which has been developed on how social shareholders perceive a company and which is also an extremely broad-scope measuring model, has drawn attention, becoming prominent in its own field and reaching a significant popularity. Charles J. Formbrun, the Reputation Institute in America, Harris Interactive, a research company again in America and Shandwick International Public Relations Company conducted a joint research and developed the reputation quotient (RQ), which is a tool standardized for determining perception of social shareholders and tangibly measuring corporate reputation. According to the Harris-Fombrun RQ Model, the understanding of all shareholders, of the corporation's current reputation, is affected by goals of the company, the level of satisfaction promised by the brand, the design of its products and consistency of effective communication and anticipatory 
strategies (Harris Interactive RQ, 2014). Beside, the Harris-Fombrun RQ Model also draws attention to the point that companies should utilize an effective feedback system in order to understand how it may be affected by factors developing in and out of control in its strategic management (Harris Interactive RQ, 2014). The Harris-Fombrun RQ Model also emphasizes the importance of adding to the concept of reputation management, new perception types such as "product purchasing" and "investment behaviors" as an extension of the connections between reputation and adjusting to changes, for the purpose of rendering a constant and strong corporate reputation (Harris Interactive RQ, 2014). The Harris-Fombrun RQ Model sorts a corporate reputation in six main headlines covering 20 basic qualities. According to this, (Harris Interactive RQ, 2014) groups the six main dimensions forming reputation as; "Emotional Attachment", "Products and Services", "Financial Performance", "Working Environment", "Vision and Leadership" and "Social Responsibility".

Shareholder perception depends on (AMPD, 2014) how much the corporation is loved and appreciated, respect and trust against the corporation in terms of emotional attachment, on the perception of quality, innovativeness, value and trustworthiness in terms of Products and Services, on the perception of profitability expectations and risks of the corporation in terms of Financial Performance, on whether the corporation possesses the qualities of an institution worth working at in terms of corporate management and staff quality. Accordingly and for this reason, product and service quality, among the components constituting corporate reputation, affect perception of the society against the organization (Watson \& Kitchen, 2010:512). Because, providing customer loyalty and adding new customer portfolios to existing ones is an assurance for the future success (Uztuğ, Şener et al., 2012:117). The dimension of staff quality emphasizes the direct relationship between corporate reputation and employees (Şatır \& Sümer; 2006:54). Enabling shareholder participation at the point of information and activity formation (Argüden, 2013:12) especially provides input at the point of employee participation to decisions through the applications of responsibility sharing with shareholders and total quality management.

The dimension of Vision and Leadership features a clear Company vision for future which enables realizing market opportunities, since connecting every application with mission, vision and values increases effectiveness of consistency and internal and external communication (Uztuğ, Şener et al., 2012:131).

Moving in line with vision and mission provides consistency and strengthens value creation (Argüden, 2013:11). This in turn, is important in terms of providing consistency. In terms of social responsibility, it is expressed that a corporation focuses on standards which it has formed at the points of environmental responsibility and sensitivity, and on sustainability of such applications. Being attentive to management principles such as transparency, openness, accountability, participation and efficiency is important in terms of reputation management (Uztuğ, Şener et al., 2012:131).

The consciousness of responsibility is an indispensable element for creation of respect and trust. Active openness, that is, transparency, is required on resource utilization inside the corporation and against society (Argüden, 2013:14). This involves possessing a self confidence which will enable reporting, presentation and opening to shareholder auditing of all studies. Correct utilization of resources becomes prominent in terms of activities in correctly managing 
performance targets. The reputation quotient (RQ) researches factors which increase or decrease reputation of a corporation, enabling reputation comparisons within and between industries. (Uztuğ, Şener et al., 2012:125).

The strategy of corporate reputation management succeeds through management of corporation's internal identification and external image (Uztuğ, Şener et al., 2012:131). It stands out that the concept of reputation is related to staff qualities, management quality, financial performance, product and service quality, customer orientation, emotional appeal, social responsibility, ethical behavior, communication and reliability components (Şatır \& Sümer;2006:54) and beside honest behaviors against rivals and transparency (Şatır \& Sümer;2006:54) also become prominent. The ability of corporations to increase their reputation values is directly proportional to the responsibilities they assume beside their financial responsibilities and all fields such as performance, communication and brand management are included in the total reputation management of a company (Uztuğ, Şener et al., 2012:131).

Fombrun expresses that reputation is an invitation to attract qualified people, major investors who will provide funds and qualified staff to the company and to establish relationship with state institutions and organizations at the necessary level (Karatepe, 2008:86). Components such as corporations' corporate social responsibility they assume in parallel to their financial responsibilities, the trust against the corporation, relationships with shareholders and service quality constitute the resource of corporate skills within the new competition conditions (Şatır \& Sümer; 2006:51) and if such parameters have been reflected on the company vision, this situation will catalyze protection of the company from possible threats and negative effects within its market and surviving risks with minimum damage. Factors such as reassuring company behaviors, its degree of realizing its promises/assurances and contributions of all organizational members in preserving the corporate reputation affect the shareholders the organization is related to (Watson \& Kitchen, 2010:512). Beside such traditionally utilized criteria which we can list as management quality, product and service quality, innovativeness, long-term investment value, financial performance, ability to attract and retain qualified individuals to/in the corporation, social and environmental sensitivity and the ability to effectively utilize corporate resources, management fields such as governance, leadership, motivation, quality management and additional value adding for customers, which are currently prominent due to intensifying effects of globalization are included in corporate reputation management components.

\section{Some Emphasis on the Intersection Point of the Concept of Governance and the Concept of Corporate Reputation Management:}

One of the concepts that have become prominent due to accelerating globalization is governance and this phenomenon has distinguished itself in the public and private sectors and third sector studies. Governance has swiftly spread due to reasons such as fulfilling increasing needs of the information society, providing a better information management, fulfilling the demand for more transparency and accountability, and reaching a wide reconciliation through intermediating between various benefits (Özer, 2006:61).

Today, the term "governance" is used to express a complex system which involves public management, private sector and non-governmental organizations and their network of relationships and interactions among themselves (Özer, 
2006:63). Also regarded as a process which consists of interconnected positions and actors of opposing benefits and coordinates various network structures, governance considers social actors as partners and is regarded as a pattern of direction and audits born out of economic, political and social actors' interactions (Özer, 2006:50). As a requirement of the sense of governance, cooperation with NGO's in many fields enables companies to establish trust-based and sustainable relationships with their shareholders and strenghten their corporate reputation (Sarıkaya \& Oruç, 2010:101). The objective of governance is to cope with both social problems and phenomena that create the complexity, dynamism and diversity of modern societies (Özer, 2006:65).

Governance balances social benefits. In this framework, it is useful to determine that concepts involved within governance, such as participation, transparency, sensitivity, equality, efficiency and productivity, responsibility and strategic vision constitute a common ground together with the components of corporate reputation management. Today, companies cooperate with NGO's as a method of gaining corporate reputation (Sarıkaya \& Oruç, 2010:96). Governance is protected by principles such as participation, transparency and accountability which constitute its basic attributes, and also involves the new sense of leadership which can support the image that requires the skill of dialogue and cooperation starting, balancing out differences, corporate performance and protection sensibility. (Özer, 2006:6569). Considering all these factors, the point that there may be a relationship between governance principles and corporate reputation management which will result in benefits for the company, may also be regarded as a determination.

\section{Corporate Reputation Management and the Key Roles of Integrated Marketing Communication and Public Relations within the Process:}

Since corporate reputation has a quite fragile structure formation and management of corporate reputation requires a strategic approach. An effective reputation management requires sending out purposeful information signals in order to positively affect the perception of all shareholders (Sarıkaya \& Oruç, 2010:96). At this point, while it is important that the vision, mission, principles and values be correctly conveyed to shareholders, the subject of communication also becomes prominent. Corporate identity translates into image through the channel of corporate communication (Tosun, 2003:186). This in turn reveals the requirement that the communication style of a company needs to be planned through a strategic approach. For this reason, integrated marketing communication, which strategically plans and coordinates communication activities that become fragmented and less effective due to traditional marketing communication methods and directly affects public relations and purchasing behaviors, assumes a key role within an organization (Bozkurt, 2002:145).

Correct reading of all shareholder expectations requires sensitivity from all company departments. Strategic handling of shareholder communication means evaluating management of shareholder perceptions directed to different expectations. Today, corporate communication has gained the quality of being a field which requires companies to conduct systematic and integrated studies (Tosun, 2003:175). That is to say; corporate reputation is the attribute of corporations against social sensitivities and corporate communication is a communication discipline which takes 
actions based on strategic communication plans in terms of sharing this "attribute" primarily with employees, and then the social shareholders in the external world (Uztuğ, Şener et al., 2012:134).

Corporate communication is a management tool where internal and external communication is effectively and productively harmonized in a deliberate manner with the groups which the company needs to be in relations with, in a way that can create a positive foundation, and is in general an integration of all communication efforts planned by companies for the purpose of implementing their strategies of outcome (Tosun, 2003:175). In corporate reputation management, the communication strategy to be implemented in order to acquire shareholder support cannot be preserved without a primary internal organizational support (Watson \& Kitchen, 2010:512). Because, the communication between groups and organizations, which we define as mutual message exchanges, whether it is verbal or non-verbal, requires a reliable message source, a correctly timed and themed message in order to succeed (Karafakığlu, 2009:156).

This requirement caused the integrated marketing communication to become prominent today. Because, the approach of integrated marketing communication is based upon the foundation that all decisions taken within the organizational structure are to be centrally strategically planned and implemented in order to realize common objectives and targets, and enables controlling and measuring all messages (Bozkurt, 2002:142). İntegrated Marketing Communication, by working in coordination with "Image and Brand Management" and "Customer Relation Management", has assumed a strategic duty within the competition environment. Integrated Marketing Communication process should be based on a sustainable communication strategy which the company needs to adopt. For this reason, Integrated Marketing Communication is a management concept which utilizes "Public Relations", "Personal Sale Technics", "Advertisement", "Promotion" and all elements of the marketing mix together, efficiently, productively and in a way that will create a synergy in the long term to constitute a strong brand image. In other words, it is the effort of providing a single sound and image for the purpose of reflecting a specific brand image and specific benefits on customers (Bozkurt, 2002:142).

It is based on the fact that all in-house activities and decisions are communication dimensions regarding customers and target audiences, that integrated marketing communication approaches to an organization in a general perspective and it plans the vision, general objectives and targets of the company related to its future (Bozkurt, 2002:142). Due to all these efforts, strengthening of the corporate reputation, provides the ability to provide customer loyalty and differentiate among rivals. Especially the efforts to bring out the concept of "benefit" in brand management activities, portraying goods and services in marketing policies as both form- and emotion- focused are due to the fact that integrated marketing communication is a bidirectional and long-term communication process which enables strategic auditing of all messages being sent to all shareholders. At this point, the purpose is to initiate a communication that will positively influence consumer purchase behavior by increasing the corporate reputation.

Due to its comprehensive dimension, controlling and management of communication messages bring fore public relations works beside integrated marketing communication in terms of corporate reputation management. Public relations assumes many important roles within the process of integrated marketing communication, (Bozkurt, 
2002:148-150) such as; resolving problems caused by strategic planning and coordination shortcomings that may be encountered in corporate structure, breaking the resistance against corporate changes through CPR, MPR, Pro-active and Re-active public relations infrastructure without the need for a new structural formation, compensating for vulnerabilities caused when the company only inclines to profit-based marketing activities within the competitive market environment and neglects the field of social responsibility, basing on ethical values in the marketing communication process and all corporate activities within the framework of social benefits and transparency, recognizing consumer attributes and behaviors against the corporation, establishing communication between corporation and the target audience and controlling this communication, harmonizing in-house activities such as total quality, corporate culture, corporate image, human resources management, crisis management with the integrated marketing communication policies. That is, public relations studies, in all their aspects, carry vital importance for strategic implementation of corporate reputation communication. Formation and checking of communication messages, the easiness of adjusting to internal and external environments bring into open the benefits that will result in common gains for all shareholders and at the same time form a bridge between integrated marketing communication and corporate reputation management.

Especially assisting the public relations department, which is to work within the field of corporate reputation communication, in ensuring fulfillment of social shareholders' needs, providing consistency and stability in realization of promises, training staff in all ranks towards effective communication with social shareholders, designing messages (Uztuğ, Şener et al., 2012:121) are important roles to be conducted at a strategic level. Corporate image, which can be qualified as the attribute and perception of the target audience towards the corporation, may create a superiority that will get the corporation ahead of its rivals through its emotional added value, and corporate image activities are conducted through corporate public relations (Tosun, 2003:174-175).

Corporate Public Relations (CPR) aims to support corporate objectives and coordinates potential communication with all the groups the corporation is in relations with (media, customers, employees, distributors, stock holders, local authorities, state, general society, unions, NGO's) (Bozkurt, 2002:147)

Advertisements used in organizational communication which includes different communication studies group involved in the area of duties and responsibilities for corporate public relations, are corporate advertisements and they realize the functions of supporting reputation, sympathy and image formation on the target audience towards the corporation, beside brand, announcement of activities and conveying required explanations to target audience at the intended places and times in periods crisis (Tosun, 2003:181). Because, corporate reputation is a contribution of the trust, created by a company, within the total market value and at the same time, the meaning of being a socially appreciated corporation in surviving crises with minimal damage. (Uztuğ, Şener et al., 2012:134). Especially in integrated marketing communication studies, it is possible to say that corporate advertisements are of utmost importance and that they create a synergy, because consumers purchase products of the companies which they trust, of which activities they are informed and which they like, with minimum hesitation (Tosun, 2003: 181). Corporate advertisements, which hold the qualities of corporate public relations studies, assist the integrated marketing 
communication, which carries the purpose of providing sales consistency and brand loyalty, formation of brand awareness, providing information, attribute formation, brand image creation, formation of purchasing intent and brand loyalty, through transferring the image from the corporation onto the products.

Marketing-oriented Public Relations (MPR) are directed to sales and its fields of activity consist of many marketingoriented activities such as positioning the corporation as a leader, creating customer trust, introducing new products, encouraging product purchases, entering new markets, increasing sales strength, acquiring retailer support and opening distribution channels (Bozkurt, 2002:147). Marketing-oriented Public Relations activities are divided into two categories, namely reactive and pro-active. While reactive public relations activities are in fields of controlling external pressure, focusing on problem solving and defending the corporation (Bozkurt, 2002:148), pro-active public relations focus on introducing product innovations and developments and following marketing opportunities (Bozkurt, 2002:147).

As a result of this understanding, going beyond reaching consumers and defining their preferences and directing their purchasing behaviors became the new trend in the field of marketing and as an extension to this, a network communication that will convey senior management applications to end users has come fore. Implemented within public relations, this study aims to develop a sustainable communication strategy in advertising and branding activities, therefore enabling differentiation. Here, very correct reading of consumer feedback gains importance for the purpose of gaining a distinctive identity to the company among many options. Especially if the company has realized innovative progress which renders it different, it should be expected that it brand be considerably ahead of its rivals in terms of communicating with consumers. At this point a new compound called "info-tainment" has gained currency. This concept, which we can define as entertaining/magazinish values becoming prominent in coding of news messages, is designed to attract consumer attention by concurrently presenting information and entertainment through media (Vikipedia, 2014). In other words, this application, constructed as a compound of "information" and "entertainment" concepts, may, in a sense, be qualified as an innovative communication type which enables strengthening of corporate social responsibility and brand image.

The increase in brand commercial value and contributions to corporate reputation of the company can be the benefits of this association. As seen, while post-modern business administration currents were trying to create differences in global markets, they also had to conduct activities in many fields that will support corporate reputation. In this sense, marketing has virtually transformed into a global talk/communication forming between companies and consumers, which aims to establish positive connections about companies and includes millions of customers in our information age (Customer Made, 2014). It is obvious that a strong corporate identity will catalyze corporate communication. Therefore, corporate reputation, with its multidimensional structure, is on the way to becoming an important agent which can be utilized in all strategic fields a company is in contact with. From the consumer perspective, preferring a corporation with a high corporate reputation brings advantages such as customer value, brand prestige, after-sale services and warranty scopes, which reduce consumer risks. It is observed that companies which form a strong communication culture and interactive relationships close to their shareholders are able to form better reputation 
perceptions (Watson \& Kitchen, 2010:512). Since advertisement activities of a company, which has managed to form a high corporate reputation perception in consumers' minds, will be more convincing, persuasive and reliable, they play important roles in supporting campaigns, promotion activities, consumers more easily adopting products and therefore increasing sales and profitability. As seen, while the concept of corporate reputation is mainly related to perception, it is also a concept which goes quite beyond and translates into profitability, that is, a tangible value, by affecting consumer preferences. A high corporate reputation which enables gaining new investors and increasing stock values, at the same time defines the weight of the company in the media.

Considering the importance of media forcefulness on companies in our day, media relations of the company enables more media coverage on advertisement activities and introduction activities included in public relations, which are named as "free advertisement". At this point, the type of media cooperation is just as important for the company as its customers, suppliers and intermediary institutions, which agents they are in contact with. Here, the "communication network" utilized by the company is especially important.

The communication network being utilized affects communication-orientation, which in turn defines accessibility to clear and correct information that is quite important in terms of effective utilization of decision-making methods needed in corporate reputation management and providing the coordination between the company and its environment. Today, especially due to the widespread internet usage and the voluminous flow of information to consumers, it has become important for companies to have original communication strategies which will assist them in differentiating themselves among their rivals.

The cacophony in the market exposed consumers to many messages and codings, and since they have become ineffective in the consumers' minds, a catchy, persistent and distinctive difference is needed within this pollution of communications. At this point, recently a particular matter of integrated marketing communication has gained currency. This is important both in terms of effective and productive resource utilization and directing of messages to the same common purpose by all components of the promotion mix and therefore easing memory retention. In addition, companies who realized the importance of social perception of the company, tend to direct their investments considering this point, moving from the point that directing this perception will in itself be a strategic power. This current which has recently gained currency and is named as "media-mania", expresses effective use of the potentials of reinforcing company position and increasing company reliability for consumers through the information to be directed from the company to the environment through media. The position media, which is directing consumer preferences, being a tool for providing news and information, requires evaluation of companies in almost every field from fulfillment of social responsibilities to declaration of ethical values, and from studies directed to the social environmental to political relations.

Media, which possesses the power to influence company shareholder and society perception in a short time, and relations to be established within this direction, will concretize through selection of a communication style which will enable strengthening corporate reputation. In order to positively influence the shareholders' perspective in the everchanging market conditions, the company needs to manage corporate reputation through a communication style which 
is understandable, interactive and takes organic connections into account (Watson \& Kitchen, 2010:512). This new understanding requires a manager who understands needs of the customers and internal and external environment of the company and coordinates strategy (Bozkurt, 2002:144)

Beside, corporate reputation communication has come fore in public information of corporate social responsibility activities, which recently became quite important for companies, and subsequently brought about the important field named "corporate social responsibility communication. Corporate social responsibility, while working towards strengthening brand image for consumers and accordingly implementing policies directed to realizing targets such as product differentiation, increasing customer loyalty and creating additional customer values, at the same time includes increasing attachment of its intellectual capital, that is, its human resources, which is a very valuable asset of it, reducing labor turnover rate, attracting qualified workforce to the company, which is in other words, keeping a high reputation also within the corporation.

An important subject of attention here is the very delicate structure of corporate social responsibility projects. Because it must not excess its real purpose/meaning in order to provide the intended contribution to company reputation and brand image. In projects concerning the whole society, structural attributes of the subject and nerve endings of the society must be very thoroughly researched and such research must be sensitively carried. Otherwise, let alone contribution, there may be extremely negative outcomes. At this very point, transparency, sharing of sincerity with the society and clear conveyance of this emotion to shareholders, sensitivity and the ability to establish a bidirectional communication become important in corporate social responsibility communication. In such senses, corporate social responsibility fulfills an important duty in terms of conveying corporate responsibility applications and messages to shareholders, enabling participation of shareholders into this process and forming positive shareholder perceptions and evaluations against the corporation and establishes a bridge between a corporation and its shareholders in terms of corporate social responsibility (Gümüş \& Öksüz, 2009:2131)

Accelerating globalization differentiated communication technologies and information / news dissemination became faster in parallel. The trust for communication is provided through information sharing between employees, and openness and transparency in problem solving (Argüden, 2013:5).

The reliability of communication must be reinforced by effective behavioral communication together with verbal communication. Consumer trust is constructed upon honesty and worthiness (Bloom, 2014). For this reason, it is required to know the industry's language, in other words, to fulfill expectations through a communication which is open and gets down to the core, in order to gain respect in the minds of the consumers. It has also become important today, to confess mistakes, in order to gain the trust of employees and customers. Accepting and swiftly reacting to mistakes leave positive impressions on brand identity (Watson \& Kitchen, 2010:512). In this sense, it might be useful to form an action plan for opting to behave honestly and trying to protect corporate reputation in such a situation instead of hiding mistakes from the society (Bloom, 2014). In addition, messages used in communication being in line with numbers and based on a logical frame are also factors which increase trust (Argüden, 2013:8). Because, too much 
talk may also lead to skepticism and lack of trust at the consumer's side, for this reason, selection of correct words and timing will be meaningful in terms of contributing to transparency and clarity (Bloom, 2014).

When shareholder experience with a company falls below expectations there is the risk of reputation (Greving, 2014). Many subjects such as how the customer relations representative treats the customer, how the human resources manager treats a candidate in hiring interviews, what the corporation promises to the audience in television advertisements and whether these promises have really been fulfilled affect corporate reputation and convey messages related to corporate reputation (Gümüş \& Öksüz, 2009:2142). Opting the way to resolve problems with shareholders, and primarily customers, within a solution-oriented and open communication while conveying them applicable information and implementing suitable arrangements and therefore inclining to reach a solution together on a common ground gains reliability and prestige to companies (Bloom, 2014).

Therefore, existence of a strong reputation management strategy will catalyze coping with risky situations in periods of crisis for the brand or the corporation (Greving, 2014). This means that the communications established / to be established by a company in every field reflects the corporate reputation and influences social and ethical values, style of presentation and shareholder perception. For this reason, communication management department of a company needs to possess the means which can research the truth value and implement communication strategies wherein feedback can be followed up and which include presentation of positive information to shareholders.

\section{Pursuing Ethical Principles in Corporate Social Responsibility Studies and its Relation with Corporate Reputation Management}

Social responsibility is a whole of activities, contributions, assistance and obligations directed to the society, of which limits the company defines upon a feeling of responsibility over results of serious evaluations conducted on social effects of its activities, taking business ethics of itself, expectations of people and institutions in its environment and laws (Özgener, 2009:162) In its essence, social responsibility is a requirement of business ethics and carries a meaning that also includes social responsibility (Aktan, 2008:103). Social responsibility is a concept which, in conducting economic activities, is related to individuals and/or companies regulating their systems in a way that these systems will develop and protect benefits of their own and the society in general (Alt1ok, 2011:150) and the necessity of balancing common benefits of various groups is constructed upon an important value as social responsibility (Özgener, 2009:85-102).

The modern world expects form companies not only natural targets such as profits, preserving existence and expansion, but also fulfillment of certain social responsibilities. In this situation, as a requirement of social responsibility, companies are to deploy their management strategy and sense of responsibility to face towards all of their shareholders, which in turn is a situation that requires making and implementing decisions related to occupational ethics (Altıok, 2011:150). Primary social responsibility fields for companies are (Özgener, 2009:85-102); protection of 
consumers and respecting consumer rights, protection of natural environment, avoiding misuse of power, increasing the quality of working life, creating areas of employment, social relief and services and respecting cultural elements of the society. This consciousness, which has to start with the existence of a company, is an organizational obligation, a contribution to the quality of social life and at the same time, a responsibility against all shareholders. Social responsibility is an important dimension which constitutes company expectations, and the most open connection of corporate social responsibility with corporation performance is the aspect of reputation (Gümüş \& Öksüz, 2009: 2141). Because companies acquire various advantages from their social responsibility projects (Saylı \& Uğurlu, 2007:93) such as increase in the level of trust, betterment of relations in various shareholder categories, acquiring a better market position, easier access to financial markets, and financial, social and managerial benefits of social responsibility projects. These factors, which will contribute positively to companies in terms of corporate reputation formation and protection, are related to ethic management, of which the importance/obligation has increased within the modern business administration of our day. For example, it is an ethical question influencing corporate reputation, that environmental problems related to a company are included in books and reported. For this (Özkol-Çelik-Gönen, 2005:139): it has become a necessity to care about subject such as -Behaving within a sensitivity for laws, environmental and social values, -Being open to information and communication, ensuring that the environment and social values are protected during services and activities in production, distribution and after-sale, -Accepting and implementing the principles of transparency and accountability. Especially due to the recent increase in environmental sensitivity, various financial regulations have been implemented and as a requirement of the concept of social responsibility, accounting information system, which is to protect all social benefits, required environmental subjects, which cause negative externalities on the society, be included within the accounting system (Özkol-Çelik-Gönen, 2005:143).

The concept of social responsibility is approached in coordination with sustainable development, and companies face the necessity to rearrange their activities in line with the sense of social responsibility (Alt1ok, 2011:150) for ensuring sustainable development. Because, the facts that societies gradually gained consciousness especially increased environmental sensitivity, and that the consumer reactions on compliance with ethical values create serious threats in terms of market standing of a company increased the sensitivity against social responsibility recently. Hence, basic future values in business administration are expressed as; protection of individual rights and freedoms, ecological wisdom, social justice, personal responsibility, social responsibility, adopting lawful behaviors, quality of life and utilization of ecologically and socially sensitive technologies (Özgener, 2009:85-102).

The concept of corporate social responsibility is the obligations of a company to protect and improve its area of activity, which obligation limits all harmful activities related to goods and services during production and in all stages leading to end user utilization and after this period (Özgener, 2009:85-102). For this reason, corporate social responsibility necessitates corporations and institutions to exhibit ethical behaviors in their relationships with their shareholders. Because corporate social responsibility involves mission, vision and values, organizational climate, social dialogue, human rights, social attention, development of local economy, environment, market relations and 
ethics and is integrated in every aspect of business studies (Gümüş \& Öksüz, 2009: 2135). It is not enough for corporations to be large and profitable in order to become reputable and companies have to obey rules of law and codes of conduct which constitute social expectation (Karatepe, 2008:87).

The need to reconcile benefits in a competition environment where customers, company owners, shareholders and managers conduct business, has conceived the concept "Managerial Ethics" (Özgener, 2009:85-102) A concept which needs to be approached together with the understanding of corporate social responsibility, necessitates understanding and management of many different values the company is in relation with. In order to ensure own actions and plans are correct for all parties, a company manager has to balance "competition on values" and "reconciliation of values", which we can define as yields of managerial ethics (Özgener, 2009:85-102) and turn this strategic subject, which is of high importance level, into an important advantage within the field of corporate reputation management.

The ability to manage the differences to be brought by this understanding can be evaluated as a strategic management management element which increases corporate reputation and reinforces corporate culture of the company, therefore contributing to competitive advantage and prepares the ground for better understanding different shareholder relations in global scale. From this perspective, corporate social responsibility studies being conducted in line with ethical principles should be expected to gain competitive advantage to the company in constructing a strong public image, supporting brand image and establishing long-term relationships with shareholders based on a foundation of trust.

The values constituting a corporation's character may be listed as ethical understanding of the corporation, its sensitivity against social responsibility and in work environment quality, labor quality and product and/or service quality and its success in corporate vision and corporate leadership applications and the approach of a corporation to these organizational values also determines the level of its reputation (Karatepe, 2008:95). Every critical factor required for success in the variable competition environment of our day is acquired through a strong reputation management. In order to acquire these yields, the concept of managerial ethics assume a key role and it is especially critically important in areas of shareholder loyalty and earning trust (Saylı \& Uğurlu, 2007:92).

Companies who ignore the reputation to be earned by compliance with ethical principles and choose to acquire high profits in short term may realize certain performance, however, the costs to be suffered as a result of ignoring the subject of reputation will operationally be much higher (Watson \& Kitchen, 2010:512). Corporate social responsibility protects reputation or brand image of a corporation and corporations acting with a sensibility of social responsibility are perceived as better than others (Gümüş \& Öksüz, 2009:2141). Ethical behavior means job security for implementers and respect, trust and reputation for a profession group (Karatepe, 2008:88). For this, ethical applications are an important part of a company's risk management (Saylı \& Uğurlu, 2007:92). Corporate reputation management is a part of organization performance and in terms of its content, it requires ethical behavior and that the leader to manage their company in a way to integrate it with the sense of social responsibility (Watson \& Kitchen, 2010:512). It is certain that corporate reputation management is closely related to leadership behaviors of a manager. At this point, since transformative leadership, as a recently emerging leadership typology, carries qualities directed to 
formation of an organizational culture climate that will bring dynamism to employees, we think this concept should be touched upon here. Translational leaders' support of interaction and information sharing between their personnel and the belief in their own competency and encouraging their staff in participation of decisions are among their attributes that become prominent at the stage of accommodating to change (Alt1ok, 2014:161). Here it must also be taken into account that the "positive feedback mechanism" in here is meticulously utilized for the purpose of positively contributing to employees and increasing their sense of responsibility (Alt1ok, 2014:161).

Communication assumes a key role in the success of corporate social responsibility activities. Again ethical principles step in at this point. When corporations convey correct messages to their shareholders using effective corporate social responsibility communication means, they are able to positively affect shareholder impressions and perceptions and transparency and pro-active standing of the communication to be established for consistency of shareholder interaction becomes prominent (Gümüş \& Öksüz, 2009: 2137-2138). The company conveying correct information to the public that it is an institution working towards public gains must be regarded as a differentiating investment towards the purpose of increasing corporate reputation.

\section{Requirement of Corporate Reputation Management to Reflect On Performance Indicators as It Involves}

\section{Human Resources Management:}

Reputation of a corporation starts within itself. It is hard to say for a corporate, the employees of which do not respect and adopt its culture and values, manages its reputation. As qualified workforce became an indicator of competition, corporate reputation takes part in bringing in highly educated employees to the company. Here, a strong feeling of belonging of the employees to the corporation shines out as a variation to be achieved. Yet, it is impossible for reputation that did not start to form within to from in the outer world (Uztuğ, Şener et al, 2012:134). Corporations may have some distinctive characteristics they want to put forward regarding corporate reputation. A corporation may put forward R\&D studies, another may put forward qualified workforce and another one may put forward processes such as financial transparency and compliance with international accounting standards (Kadıbeşegil, 2006:130-131). Here it is important to make it understood that no matter which value is chosen to be put forward, corporate reputation is a process that starts with company employees to believe in and respect on its own reputation and adopt its values and thus expands outwards. Of course financial performance indicators which can be basically stated as equity dividend, cash flow and investment return swiftness have crucial importance for companies. However, valuations based on only financial indicators remain inadequate in measuring company performance in dynamic surrounding conditions (Elitaş \& Ağca, 2006:343-344). Financial indicators of the company reflect past performance of the company (Uztuğ, Şener et al., 2012::134) and reputation is an important indicator of whether this performance will continue in the future. Sale, export or profit numbers are of course tangible data of company success, however, alongside the data showing this greatness, values such as receiving support from a large fraction of the society or being appreciated became much more important and these values started to be perceived as criterion for competition (Sarıkaya \& Oruç, 2010:96). Consequently, as a necessity of modern competition conditions, transfer to perceptions that concentrate on performance indicators such as customer satisfaction, employee satisfaction, quality, innovation 
etc. became unavoidable (Elitaş \& Ağca, 2006:343-370). Thus, based on the perception that a healthy company performance can emerge by measuring financial and non-financial performance results together in a balance, multidimensional performance valuation approaches came up (Elitaş \& Ağca, 2006:345). Performance valuation is a device that inspects in detail the success of individual on the assignment, behavior and manner at work and ethic condition and characteristics and evaluates contributions of the individual to the company (Sabuncuoğlu, 2011:184). The reason for giving importance to individual performance evaluations of organizations today is that organizational performance depends on individual performance (Tuncer, 2013:105). Because criteria used in conducting performance evaluation such as personal characteristics, reliability, diligence, compliance, leadership, work knowledge and skills affect the level of corporate reputation in the company. In this sense, one of the newest and most popular approaches in performance assessment is 360 Degree Performance Valuation Method which shines out because many personnel work with many people in organizations and there is an emerging need to receive extensive and correct feedback regarding employees from different perspectives (Camgöz \& Alperten, 2006:194).

This method aims to constantly question the system in a multifaceted way in performance assessment methodology and to collect the data on performance of the employees from various perspectives with different relations to the employees (Camgöz \& Alperten, 2006:194). The fact that this method provides opportunities to monitor both the task performance of people regarding the technical aspect of the work and the corporate performance (contextual performance) that involves interpersonal behavior and willingness based behavior (Camgöz \& Alperten, 2006:196) creates and impression that it is related to corporate reputation. Asking the performance of an employee to the colleagues, managers, subordinates, customers and teammates in a way to reflect a 360 degree aspect, provides an opportunity for the employee to look at the mirror and this provides a base for a great leap towards awareness and change. Thus, as it is an objective and multisource feedback method, it shows the strength and weakness of both the individuals and corporations.

Another current multidimensional performance assessment method which we consider it to be related to corporate reputation management is "Performance Prism Approach" Performance prism approach is based on a perception that "the companies that want to be successful in the modern business world in the long run are those that have a clear picture regarding who their partners in key positions and what they want" (Elitaş \& Ağca, 2006:343-344). Contrary to many performance valuation approaches, today, performance valuation in companies start not from the strategy but from the partners (Elitaş \& Ağca, 2006:343-370).

A prism vision is created and five dimensions of performance are evaluated in each surface of the prism. According to this, satisfaction of partners is located at the top of the prism, the base of the prism is the location of partner contributions and the three surfaces between these two are located strategies, processes and basic skills respectively (Elitaş \& Ağca, 2006:343-370). In order to create performance indicators according to performance prism, the following questions of key importance must be asked (Elitaş \& Ağca, 2006:343-370): Who are the kep partners of the company?, Which strategies must be put into action to meet the needs and demands of these key partners?, Which 
critical processes are needed to put these processes into action?, Which skills and qualifications are required to manage these processes and improve their performance?, As a company, which contributions do we require from our partners to sustain and improve these skills and qualifications?,

Creating an organizational environment to improve organizational effectiveness and efficiency also depends on the effectiveness of performance assessment system (Tuncer, 2013:105). Accordingly, if senior management and human resources department can provide the necessary environment and conditions for the employees to show organizational citizenship behavior and other behavior with similar qualities, an important competitive advantage for the success of organizations can be achieved (Bozkurt, 2011:59). Therefore, it must be taken into account by the organizations that performance assessment will be reflected on motivation and consequently on corporate reputation related studies within the organization. Thus, it must not be ignored that performance valuation methods to be utilized in human resources area are of great importance in corporate reputation management. Taking into consideration the human resources applications and processes, company must provide means for the employee to show organizational behavior in compliance with its own organizational structure (Bozkurt, 2011:59).

Today, a management understanding which will realize performance indicators based on human rights and which is created in a communicational rationality perspective in multi-actor, local and network relations is being adopted (Özer, 2006:60). In order to manage all these processes, a company first needs quality human resources, a company strategy which truly understands competition, and a strong corporate background. Thus the company, integrating common gains of its partners, will constantly have information on the level of satisfaction, requests and changing demands of its partners which are of crucial importance for corporate reputation management and these information will provide directions in strategic actions.

\section{Conclusions}

The developments in information technologies highlighted post-modern approaches of our day and in this direction, corporate reputation management have gained importance in terms of achieving differentiation in competition. Reputation of an organization forms out of organizational perceptions of its internal and external shareholders. In other words, the perception of others of the person/corporation defines the reputation. Due to movements on such a slippery ground, corporate reputation involves within itself a structure which is extremely fragile and also effective. For this reason, reputation management should be approached as a strategic element and structured in a way that will correctly determine expectations of social shareholders and satisfy each and every one of them. Because we can express that companies implementing corporate reputation management will create competitive advantage in many fields in contact with its strategic points, such as; increasing the opportunities to work with more investors, decreasing commercial risks, ease of access to global markets, getting state support in keeping up various social responsibility projects, creating finance and credit support over cooperation with institutions such as banks and insurance companies, increasing organizational commitment of personnel, surviving periods of crisis with minimal damage, surviving difficult times more easily, faster adoption of innovations by shareholders, more comfortable adoption of price sensitivity, customer loyalty, increase of sales and profitability and trust level and subsequent tangible-abstract 
credibility level. Corporate reputation, with its structure involving multidimensional components, is regarded as an important tool for strategic management especially in periods of crisis. Components of reputation which generally consist of basic components such as "Emotional Attachment", "Products and Services", "Financial Performance", "Working Environment", "Vision and Leadership" and "Social Responsibility", have currently expanded their scope due to intensifying globalization effects by also involving approaches that feature post-modern business administration, such as leadership, motivation, quality management and additional value presenting for customers.

The concept of corporate reputation management, which can be qualified as a strategic area due to the fact that it presents such a dynamic and organic structure, have come fore as an important element of sustainable competition competition today. This dimension of management which requires very delicate balances and which can be evaluated as a manifest of the employees and social ethic standing of the corporation, may, in a sense, be perceived as a motto formed by the company's reason of existence, its style of work conduct and participation in processes and all of its contributions to social gains and democracy, directed towards sustainable development. Because, corporate reputation management attributes to companies a quite high level of responsibility, which is reconciliation of the values directed to all components it comes into contact with in the society, appearing in various manifestations on all tangible and abstract values. It should also be expressed as a determination that involves intersection points in terms of basic principles with the concept of governance, which is based on the fact that the notion of corporate reputation management is in interaction with communication networks formed in cooperation with the public and private sectors and NGO's as a result of increased attention on elements such as transparency and accountability in companies due to the gradually increasing social emphasis on "clean society".

Utilization of corporate reputation as an element that will differentiate the company among its rivals depends on existence of communication that are correctly chosen and planned. Corporations intending to employ a strong corporate reputation should develop relationships directed towards best fulfillment of shareholder expectations. For this reason, it is quite important that a synergic effect is produce in all business functions. To be strengthened through effective communication strategies, this effect enables featuring of company activities especially in integrated marketing communication and public relations fields. A correctly managed corporate communication which will positively affect shareholder perceptions will enable development of a collective consciousness at a high reputation level for the company, therefore contributing a characteristic ability that is distinctive to the corporate identity. Since corporate reputation management, with an extremely delicate structure, as an extension to managing company communication style and shareholder perception directed to various expectations, requires an integrated and systematic approach, it has to be formed through a strategic understanding. For this reason, the communication side of corporate reputation, beyond traditional marketing methods, requires the key role of public relations which involves a strong unity of messages with intensified effect and efficiency and plans integrated marketing communication and communication studies which directly influence consumer purchasing behavior. Development of a communication strategy which is in line with the future vision of marketing strategies, multifaceted and sustainable, greatly contributes to provision of a productive and efficient corporate reputation management. Correct selection of message 
content, presentation place and time should be based upon communication strategies to be used in corporate reputation management. Very thorough analysis of customer feedbacks enables differentiation among rivals in terms of internalizing of effective communication in all organizational levels as a strategy, strengthening of corporate reputation, provision of customer loyalty and sustainable differentiation.

The phenomenon of corporate reputation management, which also involves the working style of the company with press/media organs, forms the understanding of "info-tainment" by combining innovative investments and strengthening of corporate social responsibility and brand images, therefore increasing commercial brand value. A content which will reflect reputation of a corporation is conveyed to shareholders either directly from the corporation itself or through channels, such as media, that can easily reach masses and has the advantages of ease of access and repeatability. Unless the company can perceive this duty as a strategic process and manages it, news with insufficient content and information pollution will be spreading from wrong channels, in other words, reputation of the corporation will be managed by rivals. For this reason, the effectiveness in the field of corporate reputation communication is of vital importance at this point. Because, since media is a channel that influences consumer preferences, corporate reputation communication should also be approached within a communication system that is open, clear, understandable and able to manage organic connections. Therefore the communication style maintained by the company will reflect corporate reputation and the company's way of presenting social and ethical values influences shareholder perception.

The modern world expects form companies not only natural targets such as profits, preserving existence and expansion, but also fulfillment of certain social responsibilities and sensitivity of companies at this point affect their corporate reputation. The concept of social responsibility is approached in coordination with sustainable development, and appeals to requirements of the shareholders to balance their common benefits. The fact that consumer reactions on compliance with ethical values pose serious threats in terms of compliance with ethical principles within the context of corporate reputation management has recently increased the sensitivity on the field of social responsibility. For this reason, corporate social responsibility, which the companies are to preserve, necessitates ethical behaviors of corporations and institutions and companies in their relationships with their shareholders.

The need for reconciliation of shareholder benefits within the competition environment has brought out the concept of "managerial ethics" which requires understanding and management of the many and different values with which the company is in relations. Managerial ethics poses a critical importance especially in terms of shareholder commitment and trust gaining. Therefore, corporate social responsibility studies being conducted in line with ethical principles should be expected to gain competitive advantage to the company in constructing a strong public image, supporting brand image and establishing long-term relationships with shareholders based on a foundation of trust. For this reason, we can say that in order for the business companies to be able to create sustainable differences within the global competition field today, they need organizations which direct their activities within framework of managerial ethical values, work with a sense of social responsibility and as an extension to these concepts, are able to effectively manage their corporate reputation. 
A corporation's reputation will primarily form within an organization climate which is respected by employees and which identifies with corporate culture and values. It should not be forgotten that qualified human resources, which we can define as "intellectual capital", will be an important element of competition and difference with its superiorities that cannot be imitated. Today, valuations based on financial indications, while carrying vital importance, are inadequate in measuring company performance in dynamic environmental conditions, therefore performance valuations wherein financial and non-financial indicators are formed in an optimum balance are required. Criteria such as satisfaction of internal and external customers, quality, the level of compliance with innovations, individual qualities, reliability, diligence, ability of adaptation, leadership qualities, business knowledge and skills affect the level of corporate reputation for a company.

An effective performance assessment system will reflect upon increasing organizational effectiveness, motivation and therefore the in-house activities related to corporate reputation. For this reason, it should not be overlooked that performance valuation methods to be implemented in human resources within the scope of organizational reputation management are important. It will enable analyzing of important elements such as formation of multidimensional performance assessment, satisfaction level of shareholders, their demands and varying expectations, in a wider angle, therefore acting like a beacon in strategic actions.

The ability of coordinating shareholders and company objectives away from conflicts and in a cooperative sense becomes a strategic value in terms of corporate reputation management. At this point, the need for a leader in corporate reputation management, who can correctly read requirements of global competition conditions, has consistently seized upon the importance of the subject and is able to reflect this on his/her vision, is decidedly quite important. In this sense, since transformative leadership, as a recently emerging leadership typology, carries qualities directed to formation of an organizational culture climate that will bring dynamism to employees, it is our conclusion that such a leader can assume important functions.

The modern business administration understanding needed by societies in the long term is at the point of forming an organizational structure which has gained the consciousness of corporate social responsibility, renders ethical values as superior, involves adopted reliable and open communication strategies against its shareholders and all values that can be utilized as competitive advantage are managed in a sense that can host social gains and which is based on the culture of reconciliation. For this reason, almost all concepts in relation with a business strategy require that corporate reputation management be emphasized. At the same time, corporate reputation management should be evaluated as an extension of the sense of democratic responsibility, which is also a requirement of our day. Adopting of corporate reputation components in a way that they can influence all processes of companies and the society in general, will assume the role of a strategic bridge which will convey the current personal/corporate reputation level in our Information Age to next generations.

\section{References}

Aktan, C. C. (2008). Professional Ethics and Social Responsibility, Work Ethics Magazine, Issue:1, May 2008, pg.99122 
Altiok, P. (2011). An Evaluation on the Sense of Social Responsibility in Implementation of Professional Ethics by Accountants, Financial Advisors and Auditing Personnel, Tax Problems Magazine, Issue:268, İstanbul, January 2011., pg:149-165. For electronic issue of the magazine:http://www.vergisorunlari.com.tr/arsiv.aspx?dsayi=268.,http://www.vergisorunlari.com.tr/makale_login.asp $\mathrm{x}$ ?makaleno $=3315$.

Altiok, P. (2014). "New Leadership Directed to Competitive Advantage in Companies: Transformative Leadership", including Pınar Altıok Gürel, Recep Yılmaz (Ed.) Leadership and its Modern Dimensions, ISBN:9786054993055., Section:6., pg:141-170., İstanbul: Derin Publishing.

AMPD.(2014). Reputation and Crisis Management AMPD., www.ampd.org/images/tr/.../06_ItibarveKrizYonetimi.ppt., Date Accessed:18.03.2014.

Argüden, Y. (2013). Reputation Management., 2nd International Reputation Management Conference, 3-4 October 2013, İstanbul., pg:1-15., http://www.slideshare.net/itibarenstitusu/2-uluslararas., Date Accessed: 22.03.2014.

Bloom, P.(2014). Let's Talk Credibility., Previous Posts., February 6, 2014 Reputation Management Strategy, Social Media and Reputation., http://www.reputationforward.com/2014/02/lets-talk-credibility/\#dispdet., Date Accessed:22.03.2014.

Bozkurt, İ. (2002). The Role of Public Relations in Integrated Marketing Communication., Gazi University Communication Faculty Magazine., 2002/16 Winter., pg:139-155., ,http://www.iletisimdergisi.gazi.edu.tr/arsiv/16.pdf., Date Accessed:28.03.2014.

Bozkurt, İ. (2011). Human Resources Applications, Examination of the Relationship Between Organizational Citizenship Behavior and Financial Performance: A Research in the Banking Sector, İstanbul University, Institute of Business Economics, Management Magazine, Year:22, Issue:70, pg:36-62, October 2011., http://journals.istanbul.edu.tr/tr/index.php/isletmeiktisadi/article/view/1884 ayrıcahttp:/www.arastirmax.com/system/files/dergiler/323/makaleler/22/70/arastirmax-insan-kaynaklariuygulamalari-orgutsel-vatandaslik-davranisi-fin-ansal-performans-arasindaki-iliskinin-incelenmesi-bankaciliksektorunde-bir-arastirma.pdf., Date Accessed: 22.03.2014.

Camgöz.,S.M. \& İ.N. Alperten.(2006)., 360-Degree Performance Assessment and Feedback: Example of a Pilot Scheme on Assessment of Managerial Competences of Department Heads in the Medicosocial Center of a University., Celal Bayar University, SEAS Management and Economy Magazine., Year:2006., Volume:13., Issue:2., pg:191-212., http://www2.bayar.edu.tr/yonetimekonomi/dergi/pdf/C13S22006/SMCINA.pdf., Date Accessed:29.03.2014.

Customer Made: Time to Tap into The Global Brain. (2014). in Trend Watching., Understanding the New Consumer., http://trendwatching.com/trends/CUSTOMER-MADE.htm., Date Accessed:28.03.2014.

Elitaş, C. \& V. Ağca. (2006). Multidimensional Performance Valuation Approaches in Companies: A Conceptual Frame, Afyon Kocatepe University, Social Sciences Magazine, 2006, 8(2), pg:343-370., http://www.aku.edu.tr/aku/dosyayonetimi/sosyalbilens/dergi/VIII2/vagca.pdf., Date Accessed:22.03.2014.

Gümüş, M. \& B. Öksüz. (2009). Key Role within Reputation Process: Corporate Social Responsibility Communication., Journal of Yasar University., 4(14), pp: 2129-2150., http://journal.yasar.edu.tr/wpcontent/uploads/2012/08/03-gumus_oksuz1.pdf., Date Accessed:29.03.2014.

Greving. A. (2014). When Transparency is Hard., Previous Posts., February 14, 2014., http://www.reputationforward.com/2014/02/when-transparency-is-hard/\#dispdet., Date Accessed:22.03.2014.

Kadıbeşegil, S. (2006). Reputation Management, 2nd Publication Istanbul: MediaCat Books., Business Books Series., İstanbul,2006.

Karafakıoğlu, M.(2009). Marketing Principles, Literatür Publishing., 2.B., İstanbul.

Karatepe, S. (2008). Reputation Management: Earning Trust in Public Relations, Electronic Journal of Social Sciences., Winter-2008., C.7., S.23., pg:77-97., ISSN:1304-0278., Winter-2008 V.7 N.23., www.esosder.org., info@esosder.org., Date Accessed:29.03.2014. 
The Harris Poll Reputation (RQ).

http://www.harrisinteractive.com/Products/ReputationQuotient.aspx., Date Accessed:20.03.2014.

Özgener, Ş.(2009). Foundations of Professional Ethics: A Managerial Approach, Nobel Publication and Distribution, 2.B., November 2009, İstanbul.

Özer, M.A. (2006). Notes on Governance., Say1ştay Magazine., Issue:63., October-December 2006., pg:59-89.

Özkol, E. \& M.Çelik \& S.Gönen. (2005). The Concept of Corporate Social Responsibility and Social Responsibility of Accounting, MUFAD Accounting and Finance Magazine, July 2005., Issue:27., pg:134-145., http://journal.mufad.org/index.php/tr/arsiv/929-sayi-27-temmuz-2005/558-kurumsal-sosyal-sorumluluk-kavrami-vemuhasebenin-sosyal-sorumlulugu., Date Accessed:28.03.2014.

Sabuncuoğlu, Zeyyat.(2011). Human Resources Management, Beta Publications, İstanbul.

Sarıkaya, M. \& İ. Oruç. (2010). Company-NGO Relationship as a Strategic Cooperation in Formation of Corporate Reputation., Magazine of Organization and Management Sciences., Volume 2, Issue 2, 2010 ISSN: 1309 -8039 (Online)., pg: 95-102., http://www.sobiad.org/ejournals/dergi_ybd/arsiv/2010_2/11muammer_sarikaya.pdf., Date Accessed:22.03.2014.

Saylı, H. \& Ö. Yaşar Uğurlu. (2007). An Evaluation for Analysis of Ethical Relationship Between Corporate Reputation and Managerial Ethics, Süleyman Demirel University SEAS Magazine, Volume: 12, Issue:3., 2007., pg:75-96., http://sablon.sdu.edu.tr/fakulteler/iibf/dergi/files/2007-3-5.pdf., Date Accessed:29.03.2014.

Şatır, Ç. \& F. Erendağ Sümer. (2006). A Research on Corporation Reputation Components: How Do Internal Shareholders Perceive Reputation in a Public Institution Producing Health Services?, 2nd International Public Relations Symposium., New Directions, Problems and Resolutions in Public Relations in teh 21st Century., 27-28 April 2006., Kocaeli University Communication Faculty., Proceedings Book., pg:50-62.., http://if.kocaeli.edu.tr/hitsempozyum2006/kitap/06cigdem_satir_Fulya_Erendag.pdf., Date Accessed:18.03.2014.

Tosun, N.B. (2003). Integrated Location of Advertisement and Image Management Within Corporate Communication Process., Marmara University Magazine of SEAS., Year:2003., Volume:XVIII., Issue:1., pg:173-191., http://dosya.marmara.edu.tr/ikf/iib-dergi/2003-1-2/2003_tosun.pdf., Date Accessed:28.03.2014.

Tunçer, P. (2013). Performance Assessment and Motivation in Organizations., Sayıştay Magazine., Issue:88., January - March 2013., pg:87-105., http://dergi.sayistay.gov.tr/icerik/der88m5.pdf., Date Accessed:29.03.2014.

Uztuğ, F. \& G. Şener \& N. Tokgöz \& S. Bayçu \& R.A. Yılmaz \& İ. Suher. (2012)., Corporate Communication., R.T. Anatolian University Publication No: 2594., Editor: Ferruh UZTUĞ., ISBN: 978-975-06-1262-6., 1.B., Eskişehir., June 2012., http://eogrenme.anadolu.edu.tr/eKitap/ILT203U.pdf.,

Date Accessed:20.03.2014.

Wikipedia. (2014). Infotainment., http://en.wikipedia.org/wiki/Infotainment., Date Accessed:28.03.2014.

Watson, T. \& P.J. Kitchen. (2010). "Reputation Management: Corporate Image and Communication”., In: Moutinho, L. and Southern, G., eds. Strategic Marketing Management: A Process-Based Approach. Andover, Hampshire: Cengage Learning., Chapter 13., ISBN: 978-1-84480-000-1., Number of Pages: 512., Deposited on: 05 Jan 2010., Last Modified:07 Mar 2013., http://eprints.bournemouth.ac.uk/12633/., \& http://eprints.bournemouth.ac.uk/12633/2/Chapter_13_def.pdf., Date Accessed:29.03.2014. 